\title{
Stress Distribution of Dental Implants in Lateral or Canine Areas: A Three-Dimensional Finite Element Analysis
}

\author{
Kanin veya Lateral Diş Bölgesine Yerleştirilen Dental Implantların Sonlu \\ Elemanlar Analizi ile Karşılaştırılması
}

\author{
Efe Can Sivrikaya', Mehmet Sami Güler ${ }^{2}$, Muhammed Latif Bekçi ${ }^{2}$ \\ ${ }^{1}$ Karadeniz Teknik Üniversitesi, Diş Hekimliği Fakültesi, Ağız Diş ve Çene Cerrahisi Ana Bilim Dalı, Trabzon \\ ${ }^{2}$ Ordu Üniversitesi, Makine Mühendisliği, Makine Bölümü, Ordu
}

Atıf/Citation: Sivrikaya, E.C., Güler, M.S. \& Bekçi, M.L. (2019). Stress Distribution of Dental Implants in Lateral or Canine Areas: A Three-Dimensional Finite Element Analysis. Ege Üniversitesi Diş Hekimliği Fakültesi Dergisi, 40(3), 141-146.

\begin{abstract}
Objectives: To evaluate stress distribution around dental implants in the areas of the canine region (CR) and the second incisor region (SIR) of the mandible in implant-supported prostheses by 3-dimensional finite analysis (FEA).

Methods: The cadaveric mandible and the Ti-6Al -4V implant with 4.0 diameter $10 \mathrm{~mm}$ length were performed in 3-D scanning and modelled. After transferred to the FEA program (Ansys 13), four variations were analyzed to represent differences in implant location (i.e., SIR or CR) with two vertical loading forces were applied to the midline (60 N) and posterior line $(100 \mathrm{~N})$ of a bar placed between implants. The von Mises and Principal stresses were evaluated by FEA.

Results: Von Mises stress analysis values are model 1: $2.7 \mathrm{MPa}$; model 2: $2.21 \mathrm{MPa}$; model 3: 9 MPa; model 4: 7.3 $\mathrm{MPa}$ and maximum-minimum Principal stress values are model 1: $0.03 \mathrm{MPa},-2.23 \mathrm{MPa}$; model 2: $0.07 \mathrm{MPa},-2.37$ MPa; model 3: 0.013 MPa, -4.59; model 4: 0.016 MPa, -5.18 MPa.

Conclusion: Von Mises and Principal stress values obtained as a result of finite element analysis were found similar in 4 different models. There is no difference in clinically.
\end{abstract}

Keywords: Inter-implant distance, Location of implants, Principal Stresses, Removable overdentures, Von Mises

\section{öz}

Amaç: İmplant destekli hareketli protez hastalarında kanin bölgesi (CR) veya lateral diş bölgesine (SIR) yerleştirilen implantlarda oluşan streslerin sonlu elemanlar analizi ile değerlendirilmesi.

Gereç ve Yöntem: Kadavra mandibulası ve 4.010 mm'lik Ti-6Al-4V implantın 3 boyutlu taraması yapılarak bilgisayar ortamında modellemesi yapıldı. ANSYS 13 programına aktarılan modellerin, implant lokalizasyonu kanin diş veya lateral diş bölgesi olmak üzere her modelde posterior birinci molar bölgesine $100 \mathrm{~N}$ veya anterior bölgede barın orta noktasına $60 \mathrm{~N}$ uygulanması ile toplam 4 farklı model analizi gerçekleştirildi. İmplantlarda meydana gelen von Mises ve Principal stres değerleri ilgili programda analiz edildi.

Bulgular: Von Mises stres analizi değerleri model 1: $2.7 \mathrm{MPa}$; model 2: 2,21 MPa; model 3: $9 \mathrm{MPa}$; model 4: $7.3 \mathrm{MPa}$ ve maksimum-minimum Principal stres değerleri model 1: $0.03 \mathrm{MPa},-2.23 \mathrm{MPa}$; model 2: 0,07 MPa, -2,37 MPa; model 3: 0,013 MPa, -4,59; model 4: 0,016 MPa, -5,18 MPa olarak belirtilmiştir.

Sonuç: Sonlu elemanlar analizi çalışması sonucu elde edilen von Mises ve Principal stres değerleri 4 farklı modelde benzer bulunmuştur. Klinik olarak bir önemi yoktur.

Anahtar Kelimeler: İmplantlar arası mesafe, İmplant lokalizasyonu, Principal stresler, Total protez, Von Mises 


\section{INTRODUCTION}

Preservation of esthetics and restoration of lost tissues has long been the main purpose of dentistry ${ }^{1}$. The invention of osseointegrated dental implants has increased the usability of prosthetic applications in edentulous patients ${ }^{2}$. Today, overdentures supported by dental implants are the primary treatment modality of edentulous patients ${ }^{3}$. Overdentures provide adequate denture stability and retention and improve patients quality of life, leading to higher denture satisfaction, including better function, speech, and comfort ${ }^{2,4,5}$. In the case of insufficient bone quantity, overdentures with attachment systems over two implants inserted in the inter-foraminal region are the best treatment method to increase prosthetic stabilization in the atrophic mandible 3,6

Biornechanical influences play an important role in prognosis of dental implants ${ }^{5,7,8}$. Occlusal loads are transmitted from dental implants to the body of mandible causing stress to the bones and dental implants. The level of stress produced depends on the diameter of the implant, design of the implant, type of implant used, surface properties of the implant, bone quality, and overdenture ${ }^{9}$. However, few studies on the effect of inter-implant distance on stress distributions have been published $^{6,10-12}$.

In this study, the stress values on implants (von Mises stresses) and surrounding bone (Principal stress values) were evaluated on the four separate models where the implants are located in the canine and second incisor regions using finite element analysis (FEA) under different loading situations. The aim of this study was to compare the von Mises and Principal stress values of lateral implants placement with canine implants placement in implant supported prosthesis.

\section{MATERIALS AND METHODS}

Four variations of implant loading and placement were modeled (Fig. 1): Model 1, canine placement, $60 \mathrm{~N}$ vertical load to the midline; Model 2, canine placement, $100 \mathrm{~N}$ vertical load to the region of the first molar; Model 3 , second incisor placement, $60 \mathrm{~N}$ vertical load to the midline; and Model 4, second incisor placement, $100 \mathrm{~N}$ vertical load to the region of the first molar. The effects of peripheral muscle and mucosal thickness were not considered in this study.

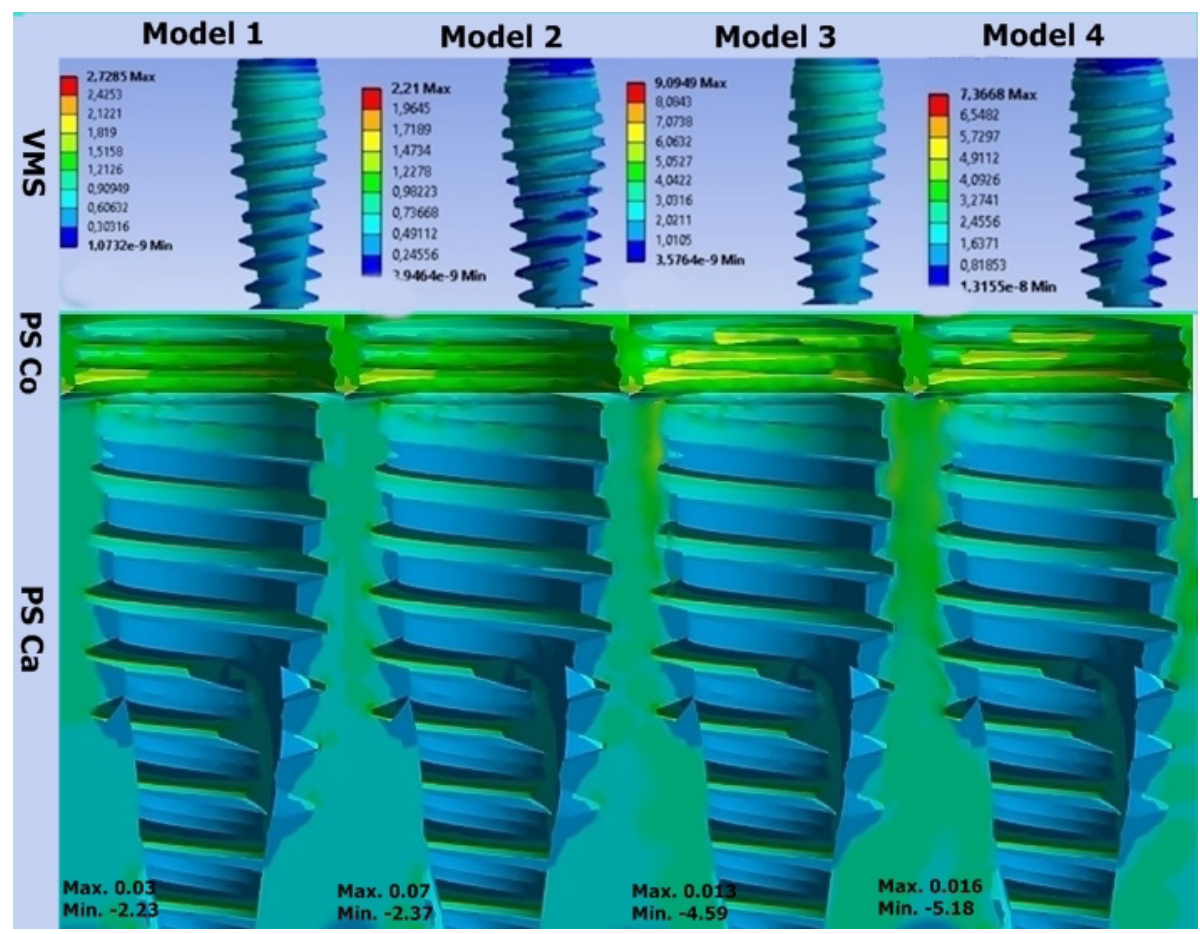

Figure 1: The stresses values on the implants and bone in four different loading conditions are presented.

VMS: von Mises Stress, PS Co: Principal stress cortical, PS Ca: Principal stress cancellous

Max: maximum Min: Minimum 
In the first simulation, a bar was assumed to connect the two implants, and a $60 \mathrm{~N}$ force was applied to the midpoint of this bar; biting with the mandibular anterior teeth was then stimulated (Fig. 2a). In the second simulation, a $100 \mathrm{~N}$ force was applied to the same region, taking into account that the biting force mainly focused on the mandibular first molar teeth (Fig. 2b). All models were loaded vertically. Because this study only evaluated the stress received by implants, forces were applied to the bar without overdenture modeling and analysis.

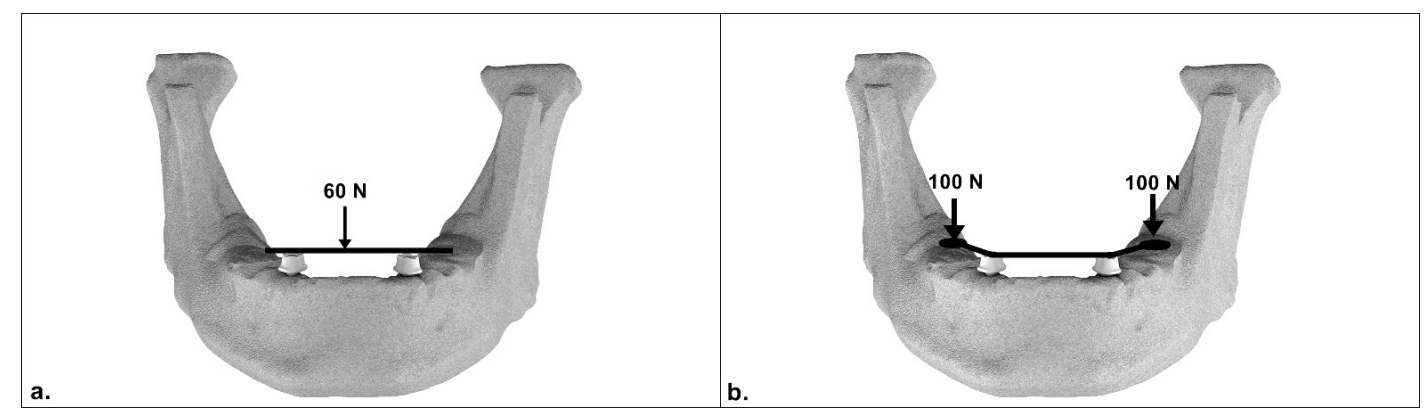

Figure 2: The application of force on the abutments.

Digital Modeling of Mandibular Jaw and Dental Implant: To obtain reliable numerical simulations, the morphometric characteristics of the mandible and implant system must be precisely reconstructed. The data obtained by computerized tomography of the dentate human mandible were transferred to a computer environment in DICOM format $(651 \mathrm{px} \times 651 \mathrm{px}, 96 \mathrm{kV}$, $0.2 \mathrm{~mm}$ thickness; Aquillion 16, Toshiba, Tokyo, Japan). Using Mimics (Mimics 10.01; Materialise, Leuven, Belgium) and SolidWorks (Solidworks Corporation, USA) software, a three-dimensional (3D) model of the edentulous mandible was created with removing the teeth (Fig. 3). Using the same software, an implant (diameter: $4.0 \mathrm{~mm}$, length: $10.0 \mathrm{~mm}$ ) was modeled according to the Nobel Active implant system (Nobel Active, Kloten, Switzerland) and placed vertically in finite element models of the mandible to simulate in vivo conditions. Finally, the model was exported to ANSYS 13 Workbench (Swanson ANSYS Inc., Houston, PA,
USA), and a mesh was automatically obtained using the same software (Fig. 4). The mesh contained 109674 elements and 179973 nodes. In this study, 100\% implantbone osseointegration was assumed.

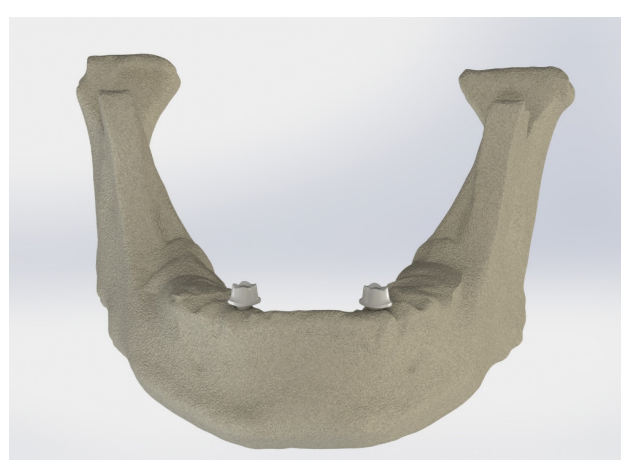

Figure 3: Digital imaging was converted into a 3D model with Mimics and Solidwork software.

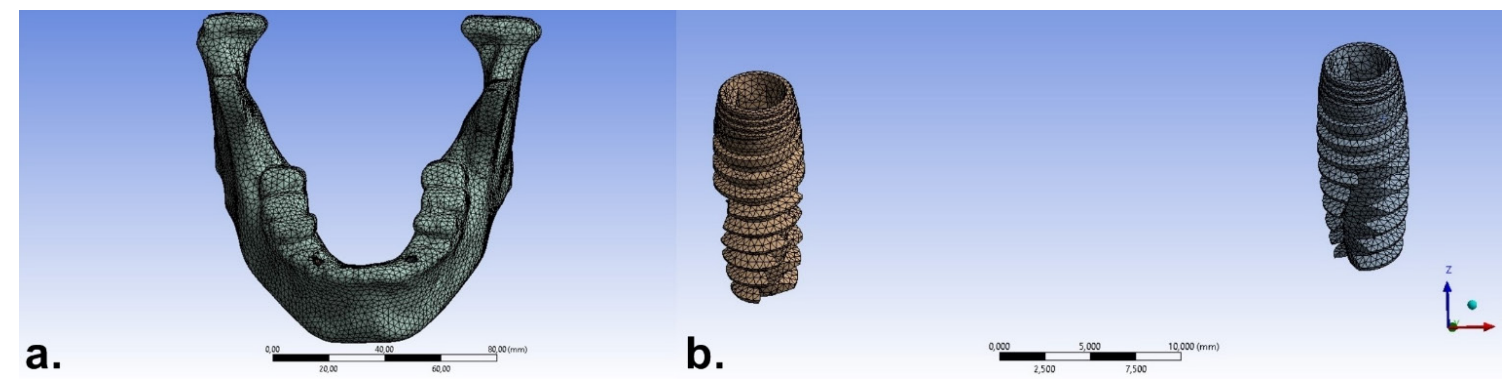

Figure 4: A mesh was obtained using the ANSYS 13 Workbench software. 
Material Properties: The Ti-6Al-4V alloy implants applied to the canine and second incisor areas were of the same length, diameter, and screw design. All the materials used in this study, such as the implant and bone, were assumed to be homogeneous, linearly elastic, and isotropic. The Young's modulus and Poisson's ratio of the materials were obtained from the literature ${ }^{14,15}$ and are shown in Table I. Von Mises stresses were visualized with blue-red colors, and figures where the stresses can be easily observed were obtained.

Boundary Conditions: The models prepared in this study were fixed to the lower and side surfaces of the mandible, and the applied forces were static.

Table 1: Young's modulus and Poisson's ratio of the materials used in the FEA study ${ }^{7},{ }^{14}$ These values were used to define the material properties in the ANSYS.

\begin{tabular}{|l|l|l|}
\hline Material & Young's modulus $(\mathrm{GPa})$ & Poisson's ratio \\
\hline Titanium & $\mathbf{1 0 3 . 4}$ & $\mathbf{0 . 3 5}$ \\
\hline Cortical bone & $\mathbf{1 3 . 7}$ & $\mathbf{0 . 3 0}$ \\
\hline Cancellous bone & 1.37 & $\mathbf{0 . 3 0}$ \\
\hline
\end{tabular}

\section{RESULTS}

In present study, four loading conditions, von Mises stresses, maximum and minimum principal stress values were compared (Fig. 1).

The respective maximum von Mises stresses under vertical loads of 60 and $100 \mathrm{~N}$ were $2.7 \mathrm{MPa}$ (model 1) and 9.0 $\mathrm{MPa}$ (model 3) for lateral implant placement 2.2 $\mathrm{MPa}$ (model 2) and 7.3 MPa (model 4) for canine implant placement. The stresses observed were clearly higher in the $1 / 3$ cervical region than in any other region studied in all models. In addition, the maximum stress tolerated by the implants was 9.0 MPa under a load of $100 \mathrm{~N}$ in the second incisor region, and the minimum stress was 2.2 $\mathrm{MPa}$ under a load of $60 \mathrm{~N}$ in the canine region.

The maximum and minimum principal stress values were as follows: model 1: $0.03 \mathrm{MPa},-2.23 \mathrm{MPa}$;model 2: $0.07 \mathrm{MPa},-2.37 \mathrm{MPa}$; model 3: $0.013 \mathrm{MPa},-4.59$; model 4: $0.016 \mathrm{MPa},-5.18 \mathrm{MPa}$. The highest stress value is at model 4 .

\section{Discussion}

Implant-retained overdentures are the primary treatment method applied to edentulous patients today ${ }^{3}$. However, the distribution of stress in dental implants remains a highly controversial issue in the literature ${ }^{1,6,7,15}$, ${ }^{16}$. Kan et al. ${ }^{6}$ described that the inter-implant distance is important in the distribution of stress. The aim of present study was the comparison of von Mises and Principal stress values of lateral and canine implant placements in implant-supported prostheses by FEA. The FEA is the adequate method for evaluating stress analyzes of implants. Few FEA studies comparing the locations of endosseous anterior implants in the edentulous mandible are available $1,6,7,17$ and most of the published research evaluates the number of implants to be applied using FEA $^{1,18}$. Topkaya and Solmaz ${ }^{1}$ reported that the stresses measured in four-implant-supported models are lower than those measured in two- implant-supported models. According to Kan et al. ${ }^{6}$, more stress occurs in bi-cortical implants than in mono-cortical implants. Meijer et al. ${ }^{7}$ also compared connected implants with solitary implants and found connected implants to experience less stress.

In previous studies, the force was applied to the implant, abutment, and prosthetic materials at an angle ${ }^{1 \text {, }}$ 6,7, 16, 17. Meijer et al. ${ }^{7}$ applied vertical, $35 \mathrm{~N}$; horizontal, $10 \mathrm{~N}$; and oblique, $70 \mathrm{~N}$ static forces on an angular bar. Topkaya and Solmaz ${ }^{1}$ applied vertical static forces to the incisor, canine, and first molar areas. Kan et al. ${ }^{6}$ applied a frontal static force of $10 \mathrm{MPa}$ to the symphysis region of the mandible. In the present study, $100 \mathrm{~N}$ static force was applied vertically to the first molar tooth region and a $60 \mathrm{~N}$ static force was applied vertically to the mandibular midline to simulate biting with the posterior tooth and biting with the incisor teeth, respectively on the bar. The present study demonstrated greater von Mises stresses and principal stresses in lateral incisor placement than in canine placement. Topkaya and Solmaz ${ }^{1}$ reported similiar results. In contrast, Kan et al. ${ }^{6}$ observed lower stress in implants placed in the lateral incisor area. In this case, the authors studied equivalent von Mises and principal stress values to evaluate the risks of bone fracture; therefore, the boundary conditions and results between their work and the present one differ. Simsek et al. ${ }^{10}$ showed that an inter-implant distance of $1.0 \mathrm{~cm}$ is the optimum distance for two-fixture implantation. In the current work, the distance between the implants placed in the right and left second incisor regions is $4.0 \mathrm{~cm}$. 
Implant-supported overdentures reportedly exert higher vertical bite forces than complete dentures. ${ }^{18}$ Tekamp et al. ${ }^{18}$ found that the bite force exerted by a twoimplant-supported prosthesis $(235 \mathrm{~N})$ was much higher than that exerted by a complete denture prosthesis (139 $\mathrm{N})$. Some studies have reported maximum biting forces of $100-150 \mathrm{~N}$ in patients with two implants ${ }^{18,19}$. In the present study, $60 \mathrm{~N}$ and $100 \mathrm{~N}$ forces were selected as bite forces to simulate two-implant-supported prosthesis and similar stress values were seen in the areas of the CR and SIR (SIR 60 and $100 \mathrm{~N}$ were 2.7 and 9.0 MPa, in the CR were 2.2 and $7.3 \mathrm{MPa}$ ).

Von Mises values are used in stress analysis of dental implants because these implants are often made of fragile materials ${ }^{10}$. In previous studies, von Mises stresses were used in stress analysis and durability testing of materials such as plates, implants, and screws. However, Schileo et al. ${ }^{20}$ found that von Mises values cannot provide accurate results, which increases the risk of implant failure. FEA involves finite element models of real objects and presents significant advantages in terms of repeatability and controllability in in vivo tests ${ }^{22}$. In fact, many studies have used FEM for stress analysis of implant loading 1,7,10,11,15,22. However, calculation of the total force exerted by an infinite number of objects is impossible; therefore, FEA cannot be as successful as clinical work in predicting stress ${ }^{10}$.

While 3D FEA affords better model simulation and more realistic stress calculations than twodimensional $\mathrm{FEA}^{7,10,22}$. Few studies on the mandible currently employ $3 \mathrm{D}$ FEA as the model database ${ }^{23}$. 3D scanners allow accurate modeling of the whole mandible; however, many other studies have been conducted by modeling only the implant placement region by FEA $8,9,24,25$.

\section{REFERENCES}

1. Topkaya T, Solmaz MY, The effect of implant number and position on the stress behavior of mandibular implant retained overdentures: A threedimensional finite element analysis. $J$ Biomech 2015;10:2102-2109.

2. Bacchi A, Consani RL, Mesquita MF, et al., Stress distribution in fixed-partial prosthesis and periimplant bone tissue with different framework materials and vertical misfit levels: a threedimensional finite element analysis. J Oral Sci. 2013;3:239-244.
FEA and limitations: In the present study, models were created to simulate the mandible completely, and some assumptions were made. First, in cadaveric mandible, only dental crowns were removed from the alveolar bone line and a toothless, smooth mandible was obtained without considering the roots and sockets. Second, while the geometry of the bone in the canine and second incisor, the mucosa, and several factors associated with implants may influence stress distributions, only the stress received by the implant (von Mises) and bone (Principal stresses) was analyzed ${ }^{26}$. Third, all of the materials used in this study, such as the implant and bone, were assumed to be homogeneous, linearly elastic, and isotropic; however, the properties of living tissues are different ${ }^{15}$. For example, the cortical bone of the mandible is isotropic and inhomogeneous in reality ${ }^{11,25}$. This study assumed $100 \%$ implant-bone osseointegration, which is highly unrealistic in actual clinical practice ${ }^{10,15,25}$.

\section{Conclusion}

In the present study, von Mises and principal stress values were higher in second incisor placement under both loading conditions. However, these stress values were close to each other so may not have clinical effect. It can be recommended that implants should be applied dependent on prosthetic planning primarily.

ACKNOWLEDGMENTS: No funds were used in the completion of this analysis. The views expressed in present study are only those of the authors.

DISCLOSURE: The authors claim to have no financial interest, either directly or indirectly, in the products or information listed in the paper.

APPROVAL: Ethical approval is not required (The analysis was done in the virtual environment).

3. Passia N, Brezavscek M, Fritzer E, et al., Single dental implant retained mandibular complete dentures--influence of the loading protocol: study protocol for a randomized controlled trial. Trials. $2014 ; 186$

4. Gehrke SA, Frugis VL, Shibli JA, et al., Influence of Implant Design (Cylindrical and Conical) in the Load Transfer Surrounding Long (13mm) and Short (7mm) Length Implants: A Photoelastic Analysis. Open Dent J. 2016;522-530.

5. Ciftci Y, Canay S, The effect of veneering materials on stress distribution in implant-supported fixed 
prosthetic restorations. Int $J$ Oral Maxillofac Implants. 2000;4:571-582.

6. Kan B, Coskunses FM, Mutlu I, et al., Effects of inter-implant distance and implant length on the response to frontal traumatic force of two anterior implants in an atrophic mandible: three-dimensional finite element analysis. Int J Oral Maxillofac Surg. 2015;7:908-913.

7. Meijer HJ, Starmans FJ, Bosman F, et al., A comparison of three finite element models of an edentulous mandible provided with implants. J Oral Rehab 1993;2:147-157.

8. Stegaroiu R, Sato T, Kusakari H, et al., Influence of restoration type on stress distribution in bone around implants: a three-dimensional finite element analysis. Int J Oral Max Impl. 1998;1:82-90.

9. Ayranci F SE, Omezli M, Is bone density or implant design more important in implant stress formation in patients with bruxism. Biotechnol Biotec Eq. 2017;6:1221-1225.

10. Simsek B, Erkmen E, Yilmaz D, et al., Effects of different inter-implant distances on the stress distribution around endosseous implants in posterior mandible: a 3D finite element analysis. Med Eng Phys. 2006;3:199-213.

11. Tabatabaian F, Saboury A, Sobhani ZS, et al., The effect of inter-implant distance on retention and resistance to dislodging forces for mandibular implant-tissue-supported overdentures. J Dent (Tehran). 2014;5:506-515.

12. Bolukbasi N, Yeniyol S, Number and localization of the implants for the fixed prosthetic reconstructions: on the strain in the anterior maxillary region. Med Eng Phys. 2015;4:431-445.

13. Meijer HJ, Starmans FJ, Bosman F, et al., A comparison of three finite element models of an edentulous mandible provided with implants. J Oral Rehabil. 1993;2:147-157.

14. Lum LB, A biomechanical rationale for the use of short implants. J Oral Implantol. 1991;2:126-131.

15. Koca OL, Eskitascioglu G, Usumez A, Threedimensional finite-element analysis of functional stresses in different bone locations produced by implants placed in the maxillary posterior region of the sinus floor. J Prosthet Dent. 2005;1:38-44.
16. Arat Bilhan S, Baykasoglu C, Bilhan H, et al., Effect of attachment types and number of implants supporting mandibular overdentures on stress distribution: a computed tomography-based 3D finite element analysis. $J$ Biomech 2015;1:130-137.

17. Chen J, Ahmad R, Suenaga H, et al., A comparative study on complete and implant retained denture treatments: a biomechanics perspective. J Biomech. 2015;3:512-519.

18. Fontijn-Tekamp FA, Slagter AP, van't Hof MA, et al., Bite forces with mandibular implant-retained overdentures. J Dent Res. 1998;10:1832-1839.

19. Ahmad R, Abu-Hassan MI, Li Q, et al., Three dimensional quantification of mandibular bone remodeling using standard tessellation language registration based superimposition. Clin Oral Implants Res. 2013;11:1273-1279.

20. Schileo E, Taddei F, Cristofolini L, et al., Subjectspecific finite element models implementing a maximum principal strain criterion are able to estimate failure risk and fracture location on human femurs tested in vitro. J Biomech. 2008;2:356-367.

21. Menicucci G, Mossolov A, Mozzati M, et al., Toothimplant connection: some biomechanical aspects based on finite element analyses. Clin Oral Implan Res 2002;3:334-341.

22. Ismail YH, Pahountis LN, Fleming JF, Comparison of two-dimensional and three-dimensional finite element analysis of a blade implant. Int $J$ oral Implantol 1987;2:25-31.

23. van Zyl PP, Grundling NL, Jooste $\mathrm{CH}$, et al., Three-dimensional finite element model of a human mandible incorporating six osseointegrated implants for stress analysis of mandibular cantilever prostheses. Int $J$ Oral Maxillofac Implants. 1995;1:51-57.

24. Levine RA, Clem DS, 3rd, Wilson TG, Jr., et al., A multicenter retrospective analysis of the ITI implant system used for single-tooth replacements: preliminary results at 6 or more months of loading. Int J Oral Maxillofac Implants. 1997;2:237-242.

25. Iplikcioglu H, Akca K, Comparative evaluation of the effect of diameter, length and number of implants supporting three-unit fixed partial prostheses on stress distribution in the bone. $J$ Dent. 2002;1:4146. 